\title{
PENGARUH LATIHAN SMALL SIDE GAME TERHADAP KETERAMPILAN PASSING SISWA SMP PLUS NURUL HUDA DALAM EKSTRAKURIKULER SEPAK BOLA TAHUN AJARAN 2020
}

\author{
Lukmanul Hakim \\ Program Studi Pendidikan Jasmani Kesehatan dan Rekreasi \\ Universitas Muhammadiyah Sukabumi \\ Email : luqmanulhakiemalsundawi10@gmail.com
}

\begin{abstract}
Abstrak: Ketepatan umpan (passing) merupakan salah satu hal yang sangat penting dalam permainan sepak bola. Banyak metode ataupun cara yang bisa dilakukan untuk melatih dan mengasah kemampuan seseorang untuk meningkatkan kualitas passing pada pemain sepak bola. Penelitian ini memiliki tujuan untuk mengetahui pengaruh latihan small side game terhadap keterampilan passing siswa SMP Plus Nurul Huda dalam ekstrakurikuler sepak bola tahun ajaran 2020. Penelitian ini merupakan penelitian eksperimen dengan menggunakan desain One-Group Pretest-posttest Design. Populasi pada penelitian ini adalah siswa ekstrakurikuler sepak bola. Sampel yang digunakan yaitu purposive sampling, dengan syarat bahwa subjek yang digunakan adalah siswa SMP Plus Nurul Huda kelas VII dan VIII yang mengikuti kegiatan ekstrakurikuler. Jumlah sampel pada penelitian ini berjumlah 16 orang. Hasil penelitian menunjukan pada nilai ratarata yang diperoleh ketika melakukan tes awal adalah 17,38 dengan simpangan baku 1,82. Sedangkan untuk nilai tes akhir adalah rata-rata 25,94 dengan simpangan baku 1,87. Hasil uji-t memperoleh nilai $\mathrm{t}_{\text {-hitung }}>\mathrm{t}_{\text {tabel }}(20,990>2,13)$, maka Ho di tolak dan Ha diterima. Dengan demikian dapat disimpulkan bahwa terdapat pengaruh latihan small side game terhadap keterampilan passing siswa SMP Plus Nurul Huda dalam ekstrakurikuler sepak bola tahun ajaran 2020.
\end{abstract}

Kata kunci : small side game, passing

Abstract: The accuracy of the pass (passing) is one of the most important things in soccer. There are many methods or ways that can be done to train and hone one's skills to improve the quality of passing on soccer players. This study aims to determine the effect of small side game training on the passing skills of SMP Plus Nurul Huda students in soccer extracurricular activities for the 2020 academic year. This research is an experimental study using the One-Group Pretest-posttest Design. The population in this study were soccer extracurricular students. The sample used was purposive sampling, with the condition that the subjects used were students of SMP Plus Nurul Huda class VII and VIII who participated in extracurricular activities. The number of samples in this study amounted to 16 people. The results showed that the average value obtained when conducting the initial test was 17.38 with a standard deviation of 1.82. As for the final test score is an average of 25.94 with a standard deviation of 1.87. The t-test results obtained the value of $t$-count $>$ t-table (20.990 > 2.13), then Ho was rejected and Ha was accepted. Thus it can be concluded that there is an effect of small side game training on the passing skills of SMP Plus Nurul Huda students in the football extracurricular activities for the 2020 academic year.

Key words: small side game, passing

History :

Submit tgl 24 November 2020, review 24 November 2020, accepted 24 November 2020 


\section{PENDAHULUAN}

Dilatar belakangi dari pendidikan jasmani, yang mana pendidikan jasmani merupakan salah satu pembelajaran yang sangat penting dan berperan aktif dalam suatu pendidikan. Pendidikan jasmani adalah bagian integral (bagian yang tidak bisa dipisahkan) dari pendidikan secara keseluruhan, yang mana pendidikan jasmani ini bertujuan untuk mengembangkan aspek kebugaran jasmani,kesehatan, stabilitas emosional, keterampilan berfikir kritis, menjalin hubungan sosial dengan baik, penalaran dan tindakan moral serta membentuk mental yang kuat.

Pendidikan jasmani juga sangat mempengaruhi terhadap keefektifan di dalam belajar. Bisa kita bayangkan serta lihat dan telaah bagaimana apabila di dalam sebuah sekolah tidak ada pendidikan jasmani. Siswa hanya dipaksa untuk belajar menghitung di dalam ruangan, siswa hanya di suapi bermacam-macam materi dari pagi sampai siang bahkan sampai sore. Bukan kenyamanan yang mereka dapatkan dalam belajar, tetapi akan semakin menimbulkan suasana yang membosankan serta membuat rasa jenuh di dalam diri siswa/i semakin besar. Materi serta praktik yang ada di dalam pendidikan jasmani menjadi salah satu kunci untuk menghilangkan rasa jenuh siswa/i di dalam belajar dan menjadikan kegiatan di dalam pembelajaran menjadi seimbang (balance).

Di dalam pendidikan jasmani tidak hanya satu anggota tubuh saja yang di gerakan. Akan tetapi semua, dari mulai tubuh bagian atas sampai tubuh bagian bawah. Tidak hanya itu, pendidikan jasmani juga memberikan perhatian proporsional terhadap domain pembelajaran yang meliputi faktor afektif, kognitif, dan psikomotor.

Pendidikan jasmani yaitu pendidikan melalui kegiatan jasmani atau gerak tubuh. Ada pepatah yang mengatakan "akal yang sehat berada di dalam tubuh yang kuat". Artinya apabila seorang siswa melakukan gerakan tubuh melalui penjas dengan baik dan teratur maka dia akan mendapatkan kecerdasan dalam berfikir serta akan selalu menghasilkan pemikiran yang positif. Karena di dalam pendidikan jasmani banyak hal di pelajari diantaranya, sikap disiplin, rasa tanggung jawab, kerjasama, rasa peduli terhadap teman, serta menjunjung nilai-nilai kejujuran dan sikap sportif. Karena pendidikan jasmani mengajarkan bahwa mereka yang disebut yang juara (The Winner) bukan orang yang mampu mengalahkan musuhnya saat bertanding, bukan orang yang memiliki banyak penghargaan, akan tetapi seorang juara ialah orang yang mengedepankan sikap jujur, tanggung jawab, disiplin, dan sportif baik saat pertandingan maupun seusai pertandingan.

Pendidikan jasmani merupakan salah satu media pembelajaran yang mana di dalam nya mendorong berbagai macam asfek yaitu, perkembangan keterampilan motorik, pengetahuan, kemampuan fisik, penalaran, penghayatan nilai sikap, emosional, mental, spiritual dan sosial, serta terdapat cara pembiasaan pola hidup sehat yang berperan 
sebagai rangsangan untuk pertumbuhan dan perkembangan yang baik dan seimbang.

Banyak terdapat materi pembelajaran di dalam pendidikan jasmani, diantaranya permainan bola besar melalui permainan sepak bola. Di dasari dari sebuah hobi serta rasa suka terhadap permainan sepak bola ini peneliti menuliskan permasalahan di dalam penelitiannya tentang "Pengaruh latihan small side game terhadap keterampilan passing siswa SMP Plus Nurul Huda dalam Ekstrakurikuler sepak bola. Permasalahan yang di dapatkan dalam penelitian ini adalah keterampilan passing yang belum akurat dalam pelaksanaannya, baik saat pertandingan maupun saat melakukan latihan. Hal ini menjadikan sebuah daya tarik kepada peneliti untuk mencari solusi dalam memperbaiki serta memecahkan permasalahan yang terjadi. Latihan small side game merupakan salah satu cara yang digunakan peneliti dalam menjawab permasalahan ini. Karena passing merupakan salah satu teknik dasar yang harus dimiliki dalam permainan sepak bola. Passing yang baik akan mempermudah teman satu tim dalam menerima bola. Sebaliknya passing yang kurang akurat akan mengakibatkan teman harus bekerja dua kali lipat untuk menerima dan menguasai bola. Bukan hanya itu, passing yang kurang baik pula akan menyebabkan kerugian yang sangat besar bagi tim.

SMP Plus Nurul Huda merupakan sekolah yang berlokasikan di Pondokleungsir RT. 24 RW. 07, desa Cisande, Kecamatan Cicantayan (43155), Kabupaten Sukabumi.
Sekolah ini juga merupakan salah satu sekolah yang di dalamnya melaksanakan program ekstrakurikuler. Ada 3 kegiatan ekstrakurikuler yang dilaksanakan yaitu, sepak bola, bola voli, dan badminton. Ekstrakurikuler sepak bola merupakan kegiatan yang sangat diminati oleh banyak siswa di sekolah ini.

Tercantum dalam UU No.20 tahun 2003 tentang sistem pendidikan nasional pasal 1 butir 12 dan 13 menyebutkan : pendidikan non formal adalah jalur atau kegiatan diluar pendidikan formal yang dapat dilakukan secara terstruktur dan berjenjang, dan pendidikan informal adalah jalur pendidikan keluarga dan lingkungan.

Sepak bola memiliki cerita dan sejarah yang sangat penting dalam setiap kehidupan suatu bangsa dan negara. Bahkan hamper semua negara mencatatkan sepak bola kedalam sejarah perkembangan negaranya. Walaupun belum begitu diketahui secara pasti tentang asal mula dan siapa yang pertama kali memainkan permainan sepak bola ini. Ada beberapa sebutan untuk permainan ini. Pada masa Cina kuno mereka menyebut olahraga ini dengan sebutan tanchu. Negara Italia menyebutnya dengan istilah haspartun. Kemudian di Prancis yang menyebar ke Normandia dan Britania (Inggris) dikenal dengan istilah choule. Dan kemudian orang Jepang menyebutnya dengan nama kemari (Kemendikbud: 2014).

Menurut Andi Mulya (2011:3) sepak bola dimainkan dewasa ini dimulai di Inggris pada pertengahan tahun 1800-an. Badan ynag mengatur sepak bola dunia adalah Federation 
Internationale de Football Association (FIFA) yang didirikan pada tahun 1904. Kemudian menggelar pertandingan sepak bola olimpiade pada tahun 1908 dan piala dunia pertama pada tahun 1930 .

Menurut Irwansyah dan Asep Kurnia Nenggala (2013) "taktik merupakan siasat atau cara yang digunakan pada saat pertandingan berlangsung untuk mencari kemenangan secara sportif. Taktik memiliki sifat yang berubah-rubah (temporal)."

Menurut Agung Setyadi (2016:22) "passing adalah suatu usaha untuk memindahkan bola dari kaki pemain ke pemain yang lain untuk membangun serangan."

Abdul Karim (2018: 52) mengatakan bahwa "Passing yang baik dimulai ketika tim sedang menguasai bola menciptakan ruang di antara lawan dengan bergerak dan membuka ruang di sekililing pemain. Keterampilan dasar mengontrol bola perlu dilatih secara berulang-ulang, sehingga pemain yang melakukan passing mempunyai rasa percaya diri untuk melakukan passing yang tegas dan terarah kepada teman satu tim yang tidak dijaga lawan. Passing yang efektif juga memberikan peluang yang lebih baik untuk mencetak gol, karena pemain yang menerima passing tersebut berada pada lokasi yang lebih menguntungkan jika dibandingkan dengan passing yang dilakukan dengan lemah atau tidak terarah.”

Latihan merupakan proses yang sistematis dalam berlatih atau bekerja yang dilakukan secara berulang-ulang dengan menambah jumlah hari maupun beban latihan dalam pekerjaannya (Harsono dalam Satriya dkk, 2014: 12).

Hipotesis penelitian bisa diartikan sebagai suatu jawaban yang masih bersifat sementara terhadap permasalahan yang ada pada penelitian sehingga bisa dibuktikan melalui data yang terkumpul (Suharsimi Arikunto, 2010:64).

\section{METODE PENELITIAN}

Dalam suatu penelitian pasti akan diperlukan suatu metode. Metode yang digunakan di dalam sebuah penelitian disesuaikan dengan masalah dan tujuan penelitiannya. Maka sebab itu metode penelitian memiliki peran penting untuk pelaksanaan pengumpulan dan analisis data. "Metode penelitian pada dasarnya merupakan cara ilmiah untuk mendapatkan data dengan tujuan serta kegunaan tertentu yang berarti penelitian harus di dasarkan pada ciri-ciri keilmuan yaitu rasional, empiris dan sistematis (Sugiyono, 2017: 2)".

Dalam sebuah penelitian ada beberapa metode yang bisa digunakan, diantaranya deskriptif, R\&D, historis, dan eksperimen. Berkaitan dengan masalah yang di dapatkan serta di kaji, maka penulis dalam penelitiannya menggunakan metode eksperimen. Sugiyono (2017: 72) menjelaskan bahwa "suatu metode penelitian yang di dalamnya terdapat perlakuan sehingga metode penelitian eksperimen dapat diartikan sebagai metode penelitian yang digunakan untuk mencari pengaruh perlakuan tertentu terhadap yang lain dalam kondisi yang terkendalikan”. 
Untuk memudahkan penulis dalam pelaksanaan program latihan yang diberikan serta sesuai dengan karakteristik permasalahan yang terdapat dalam penelitian ini, maka penulis dalam penelitiaannya menggunakan metode penelitian eksperimen dengan mencobakan suatu perlakuan dengan tujuan mengetahui seberapa besar pengaruh yang di dapatkan terhadap obyek yang dikenainya.

Oleh karenanya, metode yang digunakan dalam penelitian ini adalah metode penelitian eksperimen, dengan tujuan ingin meneliti ada tidaknya pengaruh Latihan small side game terhadap keterampilan passing.

Penelitian ini dilakukan selama 14 kali pertemuan, dengan hitungan diantaranya 2 pertemuan untuk melakukan pretest dan posttest, dan 12 kali pertemuan untuk memberikan perlakuan (treatment), karena dengan jumlah itu sudah dikatakan cukup dalam memberikan perubahan. Gede Noviada dkk dalam Ari Baskoro (2016: 20) menjelaskan bahwa dengan 12 kali melakukan latihan sudah bisa dikatakan terlatih, sebab sudah terdapat perubahan yang menetap.

\section{HASIL PENELITIAN DAN PEMBAHASAN}

Penelitian ini dilakukan di SMP Plus Nurul Huda Desa Cisande Kecamatan Cicantayan Kabupaten Sukabumi pada ekstrakurikuler sepak bola. Peneliti menggunakan 16 sampel pemain yang mengikuti kegiatan ekstrakurikuler. Sampel dalam penelitian ini yaitu siswa kelas VII dan
VIII. Penelitian yang dilakukan yaitu pengambilan data berupa penilaian terhadap keterampilan passing siswa.

Dalam penelitian ini, metode yang digunakan adalah metode eksperimen, dengan desain penelitian yaitu One-Group Pretest-Posttest Design. Dalam desain ini ada tiga tahapan pelaksanaan, yaitu tes awal (pretest), perlakuan (treatment) dan tes akhir (posttest). Treatment yang diberikan yaitu sebanyak 12 kali pertemuan dalam tiga minggu yaitu hari selasa, rabu, jum'at dan sabtu pukul 14.00 - 16.00 WIB. Pengambilan data pretest dilakukan pada hari Selasa tanggal 27 Oktober 2020, dan posttest dilakukan pada tanggal 18 November 2020 . Untuk pelaksanaan latihan diberikan antara tanggal tersebut yang dilaksanakan sebanyak 12 kali latihan. Hasil dari penelitian mengacu kepada variabel dalam penelitian ini, yaitu pengaruh latihan small side game terhadap keterampilan passing siswa SMP Plus Nurul Huda dalam ekstrakurikuler sepak bola.

Pretest tingkat keterampilan passing siswa ekstrakurikuler SMP Plus Nurul Huda memiliki skor nilai minimum (nilai minimal) 14, skor nilai maximum (nilai maksimal) 20, mean (rata-rata) 17.38, median (nilai tengah) 18.00, modus (nilai sering muncul) 18, dan standar deviasi (simpangan baku) 1.82 . Deskripsi hasil penelitian ini dapat dilihat pada tabel sebagai berikut : 
Tabel 1 Skor Nilai (Pretest)

\begin{tabular}{|c|c|}
\hline Skor Nilai & Frekuensi \\
\hline $14-15$ & 3 \\
\hline $16-17$ & 4 \\
\hline $18-19$ & 1 \\
\hline 20 & 16 \\
\hline
\end{tabular}

Berdasarkan distribusi frekuensi hasil

penelitian pretest, apabila ditampilkan dalam bentuk grafik, maka dapat dilihat pada gambar berikut :

\section{Gambar 1 Grafik Hasil Pretest Passing}

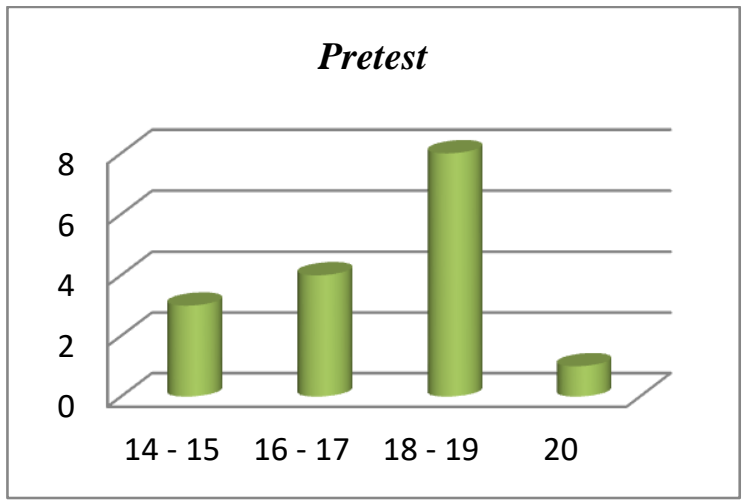

Posttest tingkat keterampilan passing

siswa ekstrakurikuler SMP Plus Nurul Huda memiliki skor nilai minimum (nilai minimal) 24, skor nilai maximum (nilai maksimal) 30, mean (nilai rata-rata) 25,94, median (nilai tengah) 26.00, modus (nilai sering muncul) 24 dan standar deviasi (simpangan baku) 1.87 .

Apabila di tulis dalam tabel, maka deskripsi hasil penelitian tersebut dapat dilihat di bawah ini :
Tabel 2 Skor Nilai (Posttest)

\begin{tabular}{|c|c|}
\hline Skor Nilai & Frekuensi \\
\hline $24-25$ & 7 \\
\hline $26-27$ & 6 \\
\hline $28-29$ & 2 \\
\hline 30 & 16 \\
\hline Jumlah & \\
\hline
\end{tabular}

Berdasarkan distribusi frekuensi hasil penelitian posttest, apabila ditampilkan dalam bentuk grafik maka dapat dilihat gambar sebagai berikut :

\section{Gambar 2 Grafik Hasil Posttest Passing}

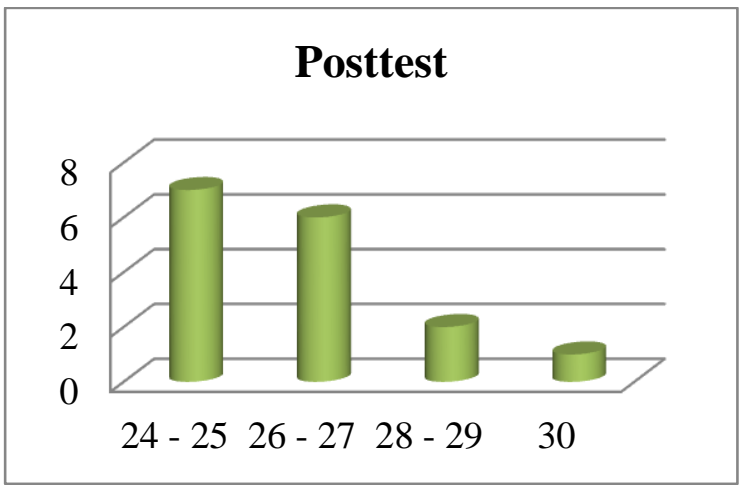

Sebelum dilakukan analisis statistik, maka terlebih dahulu dilakukan uji pesrsyaratan analisis atau uji asumsi yang mana di dalamnya meliputi uji normalitas dan uji homogenitas. Uji normalitas ini dilakukan untuk mengetahui normal atau tidak nya distribusi dari data yang diperoleh. Sedangkan uji homogenitas dilakukan yaitu untuk mengetahui apakah sampel yang digunakan dalam penelitian berasal dari populasi yang homogen.

$$
\text { Pengujian normalitas yaitu }
$$
menggunakan uji Kolmogorov - Sminrov test. Dalam uji ini akan dilakukan pengujian 
hipotesis sampel yang berasal dari populasi berdistribusi normal, dengan membandingkan harga Asymp. Sign dengan 0,05 untuk mengetahui apakah hipotesis diterima atau di tolak. Dimana apabila Asymp. Sign lebih besar dari 0,05 maka hipotesis diterima. Apabila Asymp. Sign lebih kecil dari 0,05 maka hipotesis ditolak.

Tabel 3 Hasil Perhitungan Uji Normalitas

\begin{tabular}{|c|l|c|c|}
\hline NO & Variabel & Asymp.Sign & Kesimpulan \\
\hline 1 & Pretest & 0,098 & Normal \\
\hline 2 & Posttest & 0,200 & Normal \\
\hline
\end{tabular}

Dari tabel diatas diketahui bahwa harga Asymp. Sign dari variabel pretest adalah sebesar 0,098 dan dari variabel posttest sebesar 0,200. Dari hasil tersebut, ditarik kesimpulan bahwa karena harga Asymp. Sign dari kedua variabel tersebut lebih besar dari 0,05 maka hipotesis dari sampel berdasarkan dari populasi yang berdistribusi normal diterima.

Uji homogenitas yang dilakukan bertujuan untuk mengetahui data yang diperoleh memiliki varians yang homogen atau tidak. Dengan kata lain apakah dari kelas tersebut memiliki pemahaman terhadap passing yang homogen atau tidak. Selain itu, dalam melakukan uji homogenitas juga bertujuan untuk menguji hipotesis bahwa varians dari variabel-variabel tersebut sama, yaitu membandingkan nilai signifikan lebih dari 0,05 dengan hipotesis apakah diterima atau di tolak.

Hasil uji homogenitas tersebut dapat dilihat pada tabel sebagai berikut :
Tabel 4 Hasil Perhitungan Uji

Homogenitas

\begin{tabular}{|c|c|c|}
\hline $\begin{array}{c}\text { Nilai } \\
\text { Signifikansi }\end{array}$ & $(0,05)$ & Kesimpulan \\
\hline 0,984 & 0,05 & Homogen \\
\hline
\end{tabular}

Dari hasil perhitungan tersebut diperoleh signifikansi sebesar 0,984>0,05, yang memiliki arti bahwa sampel varian tersebut homogen. Maka hipotesis yang menyatakan varians dari variabel yang ada adalah sama atau diterima. Maka dari itu dapat disimpulkan bahwa varians populasi homogen.

Penelitian ini dilakukan yaitu untuk mengetahui pengaruh yang di dapatkan dari metode latihan small side game terhadap keterampilan passing siswa SMP Plus Nurul Huda pada ekstrakurikuler sepak bola. Dengan demikian berdasarkan hasil penelitian yang dilakukan, ini menunjukan bahwa terdapat pengaruh dari pelaksanaan latihan small side game terhadap keterampilan passing siswa SMP Plus Nurul huda, ini dibuktikan dengan hasil nilai uji thitung yaitu $20.990>2.13$ (t tabel) dan nilai signifikansi sebesar 0,000<0,05 ( $\mathrm{sig}<0.05)$. sebelum diberikan latihan small side game kepada siswa yang mengikuti ekstarkurikuler di SMP Plus Nurul Huda, kemampuan passing mereka berada pada rerata 17.38 dan pada saat posttest (setelah diberikan treatment) kemampuan mereka dalam melakukan passing yaitu 25.94. dan ternyata setelah diberikan latihan small side game besarnya rerata mereka bertambah yaitu 8.562 atau sebesar $49,2 \%$. 
Apabila digambarkan dalam bentuk grafik perbandingan hasil pretest dan posttest dapat dilihat dibawah ini :

Gambar 3 Perbandingan Rata-rata Pretest dan Posttest

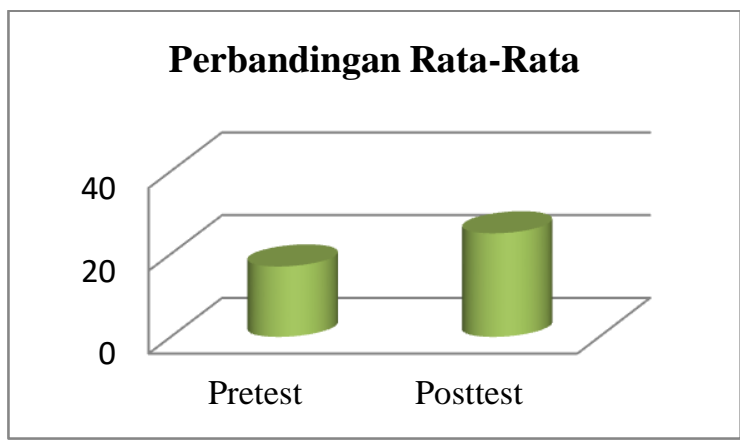

Latihan small side game yang dilakukan memberikan lebih banyak sentuhan terhadap bola oleh siswa dalam melakukan permainan sepak bola. Bukan hanya itu, dalam permainan small side game juga siswa mendapatkan lebih banyak waktu untuk melakukan latihan. Kondisi fisik serta kemampuan (skill) mereka juga semakin terlatih, sehingga membuat kondisi fisik dan kemampuan siswa semakin meningkat.

Setiap pemaian dalam permainan sepak bola harus memiliki teknik dasar, guna untuk mempermudah mereka dalam menguasai pertandingan di dalam lapangan. Passing merupakan salah satu teknik dasar penting yang harus dimiliki oleh pemain sepak bola, terutama dalam memberikan umpan kepada temannya. Mudah atau susahnya teman saat menerima umpan tergantung passing yang diberikan sebelumnya. Latihan passing dengan melakukan permainan small side game memiliki tujuan memberikan latihan dengan tingkat kesulitan yang besar, sehingga seorang pemain lama-kelamaan menjadi nyaman dan terbiasa dalam melakukannya, dan membuat kemampuan passing mereka juga semakin bagus dan terarah.

Latihan small side game yang dilakukan memberikan lebih banyak sentuhan terhadap bola oleh siswa dalam melakukan permainan sepak bola. Bukan hanya itu, dalam permainan small side game juga siswa mendapatkan lebih banyak waktu untuk melakukan latihan. Kondisi fisik serta kemampuan (skill) mereka juga semakin terlatih, sehingga membuat kondisi fisik dan kemampuan siswa semakin meningkat.

Setiap pemaian dalam permainan sepak bola harus memiliki teknik dasar, guna untuk mempermudah mereka dalam menguasai pertandingan di dalam lapangan. Passing merupakan salah satu teknik dasar penting yang harus dimiliki oleh pemain sepak bola, terutama dalam memberikan umpan kepada temannya. Mudah atau susahnya teman saat menerima umpan tergantung passing yang diberikan sebelumnya. Latihan passing dengan melakukan permainan small side game memiliki tujuan memberikan latihan dengan tingkat kesulitan yang besar, sehingga seorang pemain lama-kelamaan menjadi nyaman dan terbiasa dalam melakukannya, dan membuat kemampuan passing mereka juga semakin bagus dan terarah.

\section{KESIMPULAN}

Berdasarkan hasil penelitian yang telah diperoleh dengan analisis data serta pengujian hipotesa mengenai pengaruh latihan small side game terhadap keterampilan passing siswa SMP Plus Nurul 
Huda dalam ekstrakurikuler sepak bola tahun ajaran 2020, maka dapat ditarik kesimpulan bahwa, "Terdapat pengaruh metode latihan small side game terhadap keterampilan passing siswa SMP Plus Nurul Huda dalam ekstrakurikuler sepak bola tahun ajaran 2020. Hal ini dapat dibuktikan dengan hasil dari nilai rata-rata yang diperoleh ketika melakukan pretest yaitu sebesar 17,38 dengan simpangan baku yaitu 1,82. Sedangkan ketika melakukan posttest memiliki nilai rata-rata yaitu 25,94 dengan simpangan baku yaitu 1,87. Dapat ditarik kesimpulan bahwa adanya peningkatan dari hasil pretest dan posttest. Dilihat dari perbandingan antara mean difference $(8,562)$ dengan mean pretest $(17,38)$, maka peningkatan yang dihasilkan sebesar 49,2\% .

\section{DAFTAR PUSTAKA}

Suharsimi Arikunto (2010). Prosedur Penelitian. Yogyakarta: PT Renika Cipta.

KEMENDIKBUD. (2014). Pendidikan Jasmani, Olahraga dan Kesehatan. Jakarta: Pusat Kurikulum dan Perbukuan.

Irwansyah, Asep Kurnia Nenggala. (2013). Pyisical Education, Sport and Health. Bandung: Grafindo Media Pratama.
Harsono. (2015). Periodesasi Program Latihan. Bandung: PT Remaja Rosdakarya.

Agung Setyadi. (2016). Pengaruh Latihan Small Side Game Terhadap Keterampilan Passing Siswa Peserta Ekstrakurikuler Futsal di SMP Muhammadiyah 2 Depok Sleman Tahun 2016. Yogyakarta: Fakultas Ilmu Keolahragaan Universitas Negeri Yogyakarta.

Ari Singgih Baskoro. (2016). Pengaruh Latihan Small Side Game Terhadap Kebugaran Jasmani Siswa Peserta Ekstrakurikuler Sepak Bola di SMP Negeri 1 Pakem Sleman Tahun 2016. Yogyakarta: Fakultas Ilmu Keolahragaan Universitas Negeri Yogyakarta.

Abdul Karim. (2018). Pengaruh Latihan Small Side Game Terhadap Peningkatan Ketepatan Passing Dengan Kaki Bagian Dalam Pada Siswa Peserta Ekstrakurikuler Sepak Bola MTs Ali Maksum Bantul. Yogyakarta: Fakultas Ilmu Keolahragaan Universitas Negeri Yogyakarta.

Andi Mulya. (2011). Ensiklopedia Olahraga Indonesia. Bandung: Angkasa.

Sugiyono. (2017). Metode Penelitian Kuantitatif, Kualitatif dan $R \& D$. Bandung: Alfabeta. 